\title{
THE PROLONGATION OF THE ACTION OF SUBCUTANEOUSLY INJECTED MEDICINES IN MAN
}

\author{
By FRANCIS F. FOLDES 1 \\ (From the C Medical Service and the Central Laboratory of the Jewish Hospital, Budapest)
}

(Received for publication October 1, 1942)

The effect of certain metals $(\mathrm{Zn}, \mathrm{Co}, \mathrm{Ni}, \mathrm{Cu}$, $\mathrm{Al}, \mathrm{Fe}$, etc.) and tannin, in prolonging the action, of various substances injected subcutaneously into animals, has been demonstrated by many workers. Perhaps the first observations in this direction were made by Bertrand and Mâcheboeuf (1) in 1926 . They found that the addition of small quantities of $\mathrm{Co}$ and $\mathrm{Ni}$ salts increased and prolonged the effect of insulin. Extensive work in this field began after 1934. The possibility of prolonging the effect of pituitary gonadotropic hormone (2), insulin (3), the antidiuretic principle of the posterior lobe pituitary extracts (4), histamine (4.a), epinephrine (5), and morphine (6) has been repeatedly shown in various animal experiments.

Notwithstanding the clinical success obtained by prolonging the action of insulin (7) and posterior pituitary extract (8), little work has been done in this important field with regard to other medicines, employed subcutaneously in man. The object of this paper is to show that by the addition of $\mathrm{Zn}$, it is possible to prolong in man the activity of various substances, which greatly differ both in chemical composition and pharmacological action.

\section{METHODS AND MATERIAL}

The drugs employed in the following experiments were: Posterior lobe pituitary extract, ${ }^{2}$ epinephrine, ${ }^{3}$ and thiamine.4 Posterior pituitary extract was chosen partly because of the encouraging results attained by its combination with $\mathrm{Zn}_{\mathrm{n}}$ in animal experiments, and partly because we had the opportunity to observe, in a comparatively short period, a number of diabetes insipidus cases. A preliminary report on the therapeutic use of posterior pituitary extract with $\mathrm{Zn}$ was published by us recently (8.e). The choice of epinephrine was made because of the contrast between the good results obtained in rabbit experiments (5 and 9) and the negative experi-

1 Resident in Anesthesia, Massachusetts General Hospital, Boston.

2 Pituisan (Chinoin, Budapest).

3 Tonogen (Richter, Budapest).

4 Vitaplex $B_{1}$ (Chinoin, Budapest). ments of Kohn and Bulger (10) in man. Because both posterior pituitary extract and epinephrine are vasoconstrictor agents and hormones, thiamine was chosen to demonstrate that the same principle can be employed on a wholly different substance.

The experiments with posterior pituitary extract were carried out on 3 individuals with normal water metabolism, and 7 patients, of whom 5 were suffering from diabetes insipidus and 2 from polyuria of undisclosed nature. In the present paper, only the observations made on 2 normals and 3 diabetes insipidus patients will be recorded. The investigations with epinephrine were made on 4 hospitalized patients with normal cardiovascular systems (one of them suffering from bronchial asthma), 8 dental patients, and 4 ambulatory patients with bronchial asthma. The subjects in the thiamine experiments were 5 hospitalized patients and 2 physicians, who volunteered for the purpose. Exactly the same amount and concentration of the various substances was injected into the subcutaneous tissue of the gluteal region, on one occasion without $\mathrm{Zn}$ and on the other mixed with $\mathrm{Zn}$ in a previously determined optimal concentration. This concentration ranged from 0.06 to 0.10 per cent. $\mathrm{Zn}$ was added in the form of $\mathrm{ZnCl}_{2}$. For reasons to be explained later, the $\mathrm{pH}$ of the injections was kept around 5.5. In the case of posterior pituitary extract and epinephrine, the pharmacological action and the presence or absence of unwanted side effects was observed. With thiamine, the rate of excretion in urine was followed.

Throughout this paper in the figures and tables, the following abbreviations will be used: For posterior pituitary extract, PPE; for epinephrine, Adr; and for thiamine, $\mathbf{B}_{\mathbf{1}}$.

\section{OBSERVATIONS}

\section{The influence of zinc on the antidiuretic ac- tivity of posterior pituitary extract ${ }^{5}$}

To study the effect of $\mathrm{Zn}$ on the antidiuretic activity of posterior pituitary extract, the rate of urine excretion was observed after the administration of $1000 \mathrm{cc}$. of tap water, in 2 persons with normal water metabolism and in 3 diabetes insipidus patients.

For persons with normal water metabolism, the arrangement of the experiment was the following:

5 Dr. I. Strausz (Budapest) cooperated in the posterior pituitary extract experiments. 


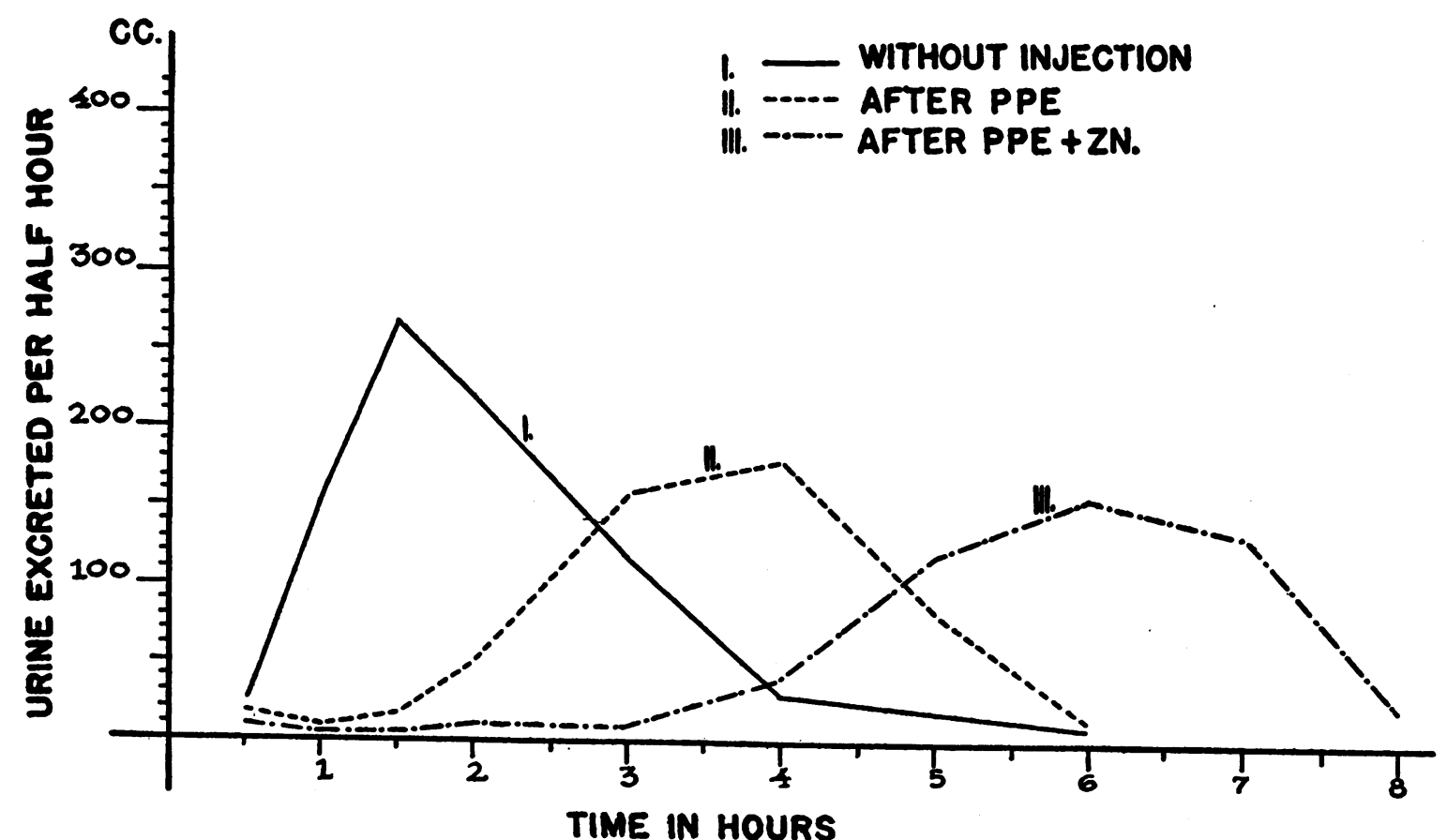

Fig. 1.a

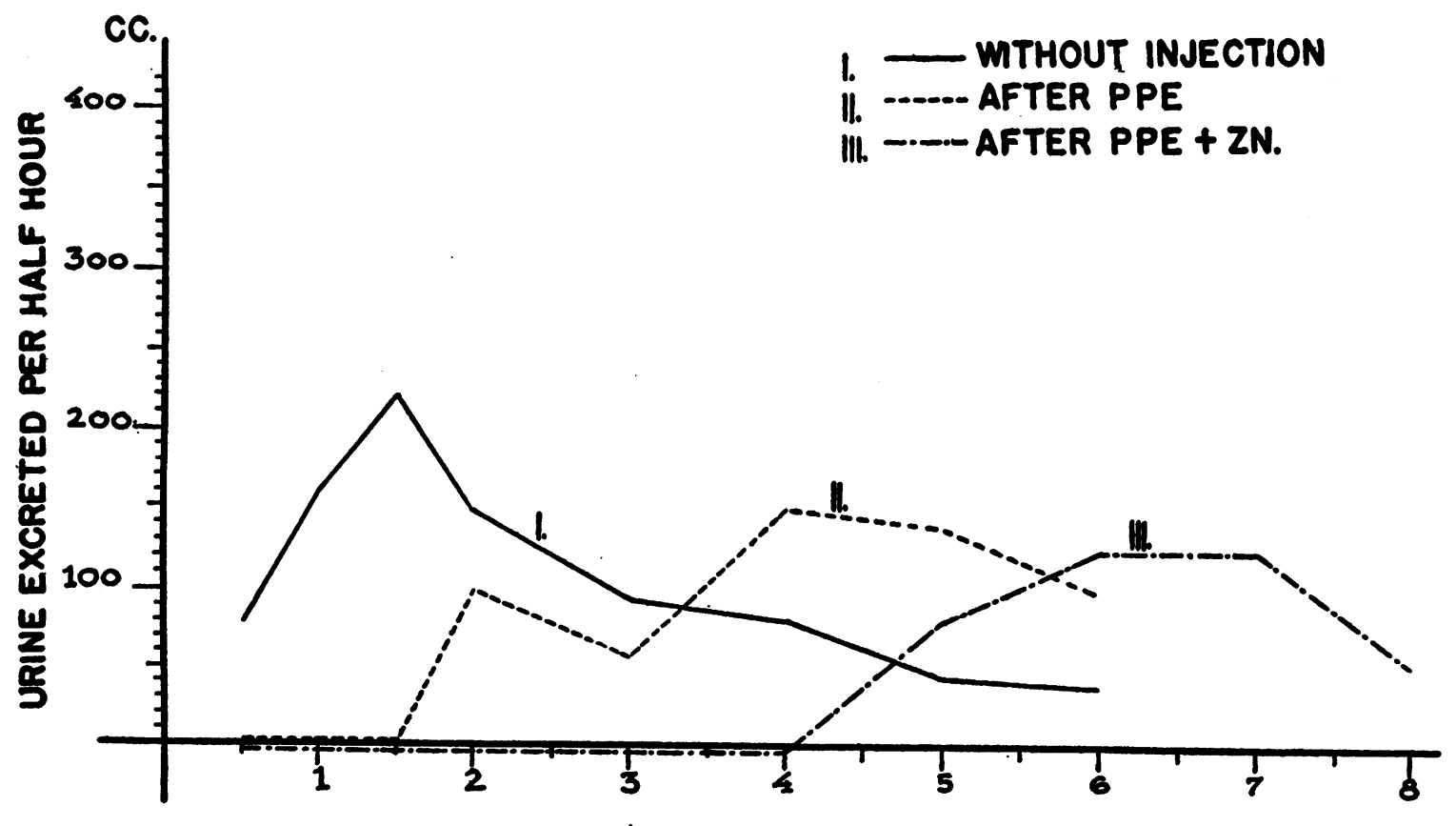

TIME IN HOURS

Fig. 1.b

Figs. 1.a and 1.b. The Urine Excretion Curves of Patients B. S. and S. N. With Normal Water Metabolism, Following the Intake of 1000 cc. of TAP Water

I. Without medication; II. after the subcutaneous injection of 0.4 I.U. of posterior pituitary extract; III. after the subcutaneous injection of $0.4 \mathrm{I} . \mathrm{U}$. of posterior pituitary extract with $0.4 \mathrm{mgm}$. of zinc. 
The individuals were kept in bed 10 to 12 hours before and 5 to 8 hours during the experiments, and no food or fluid was allowed during this period. The bladder was completely emptied before the beginning of the experiment. Immediately afterwards, $1000 \mathrm{cc}$. of tap water were consumed within 5 to 10 minutes. Urine was then passed $1 / 2,1,1 \frac{1}{2}, 2,3,4,5$, and 6 hours after the water intake. A few days later the experiment was repeated with the difference that simultaneously with the administration of water, 0.4 I.U. of posterior pituitary extract, diluted to $0.4 \mathrm{cc}$., was injected in the subcutis of the gluteal region. On yet another occasion, the same amount of posterior pituitary extract was injected with $0.4 \mathrm{mgm}$. of $\mathrm{Zn}$ (in the form of $\mathrm{ZnCl}_{2}$ ) so that the $\mathrm{Zn}$ concentration of the injection was 0.1 per cent. The half-hourly urine excretion produced under different conditions was charted against time (Figures 1.a. and 1.b.).

Figures 1.a and 1.b show that in normal persons, the urine excretion curve reaches its maximum $1 \frac{1}{2}$ hours after water administration. If simultaneously with the water intake, 0.4 I.U. of posterior pituitary extract $(1 / 25$ of the therapeutic dose usually applied) is injected subcutaneously, then the maximum is shifted to the fourth hour, and if the same amount of posterior pituitary extract is injected, well mixed with $\mathrm{Zn}$, the maximum is reached only in the sixth hour. Furthermore, it can also be seen that under physiological conditions, urine excretion starts immediately after the consumption of fluid. While the injection of 0.4 I.U. of posterior pituitary extract hinders any significant urine production for $11 / 2$ hours, the admixture of $\mathrm{Zn}$ to the same amount of posterior pituitary extract causes suspension of urine excretion for 3 to 4 hours. This increased activity, incident to the admixture of $\mathrm{Zn}$, can be best

TABLE I

Total amount of urine collected up to the times indicated

\begin{tabular}{c|c|c|c|c|c|c}
\hline \hline \multirow{2}{*}{$\begin{array}{c}\text { Time } \\
\text { from } \\
\text { water } \\
\text { intake }\end{array}$} & \multicolumn{3}{|c|}{ B.S. } & \multicolumn{3}{|c}{ S.N. } \\
\cline { 2 - 7 } & $\begin{array}{c}\text { Without } \\
\text { injection }\end{array}$ & $\begin{array}{c}\text { After } \\
\text { PPE }\end{array}$ & $\begin{array}{c}\text { After } \\
\text { PPE }+Z n\end{array}$ & $\begin{array}{c}\text { Without } \\
\text { injection }\end{array}$ & $\begin{array}{c}\text { After } \\
\text { PPE }\end{array}$ & $\begin{array}{c}\text { After } \\
\text { PPE +Zn }\end{array}$ \\
\hline $\begin{array}{c}\text { hours } \\
1\end{array}$ & $c c$. & $c c$. & $c c$. & $c c$. & $c c$. & $c c$. \\
3 & 179 & 28 & 16 & 240 & 0 & 0 \\
6 & 1018 & 417 & 51 & 802 & 220 & 0 \\
& 962 & 687 & 1125 & 1000 & 410 \\
\hline
\end{tabular}

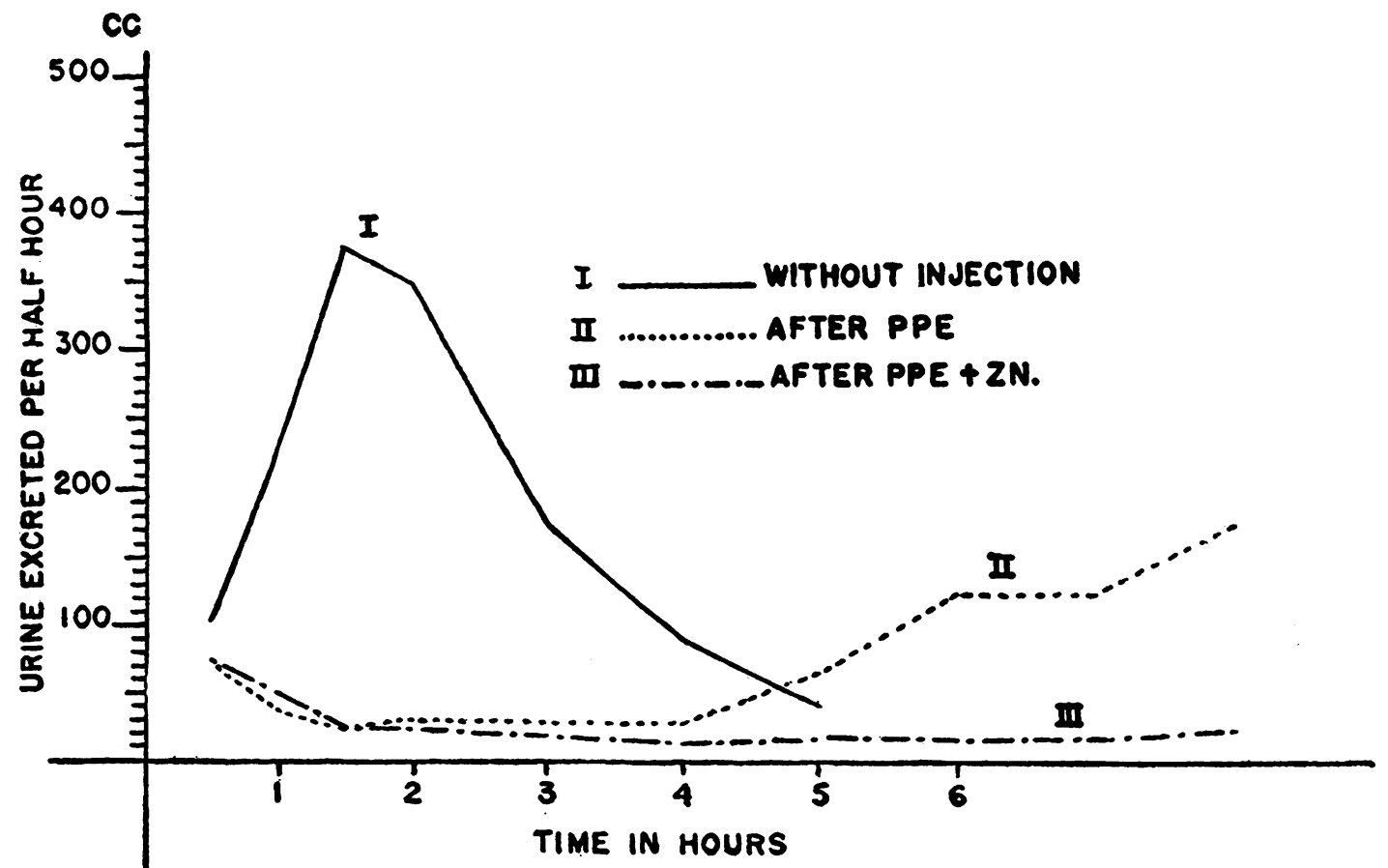

Fig. 2.a 


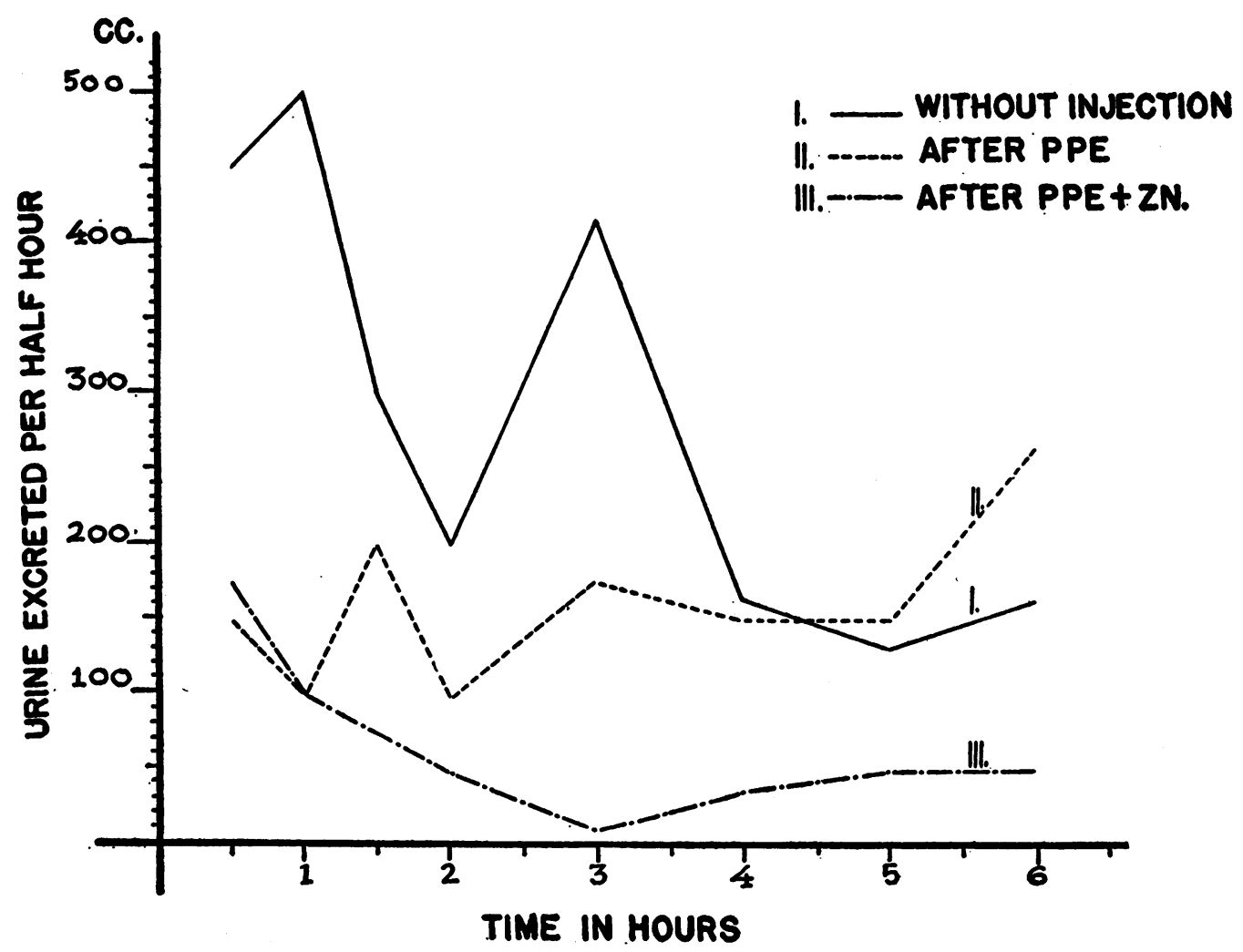

Fig. 2.b

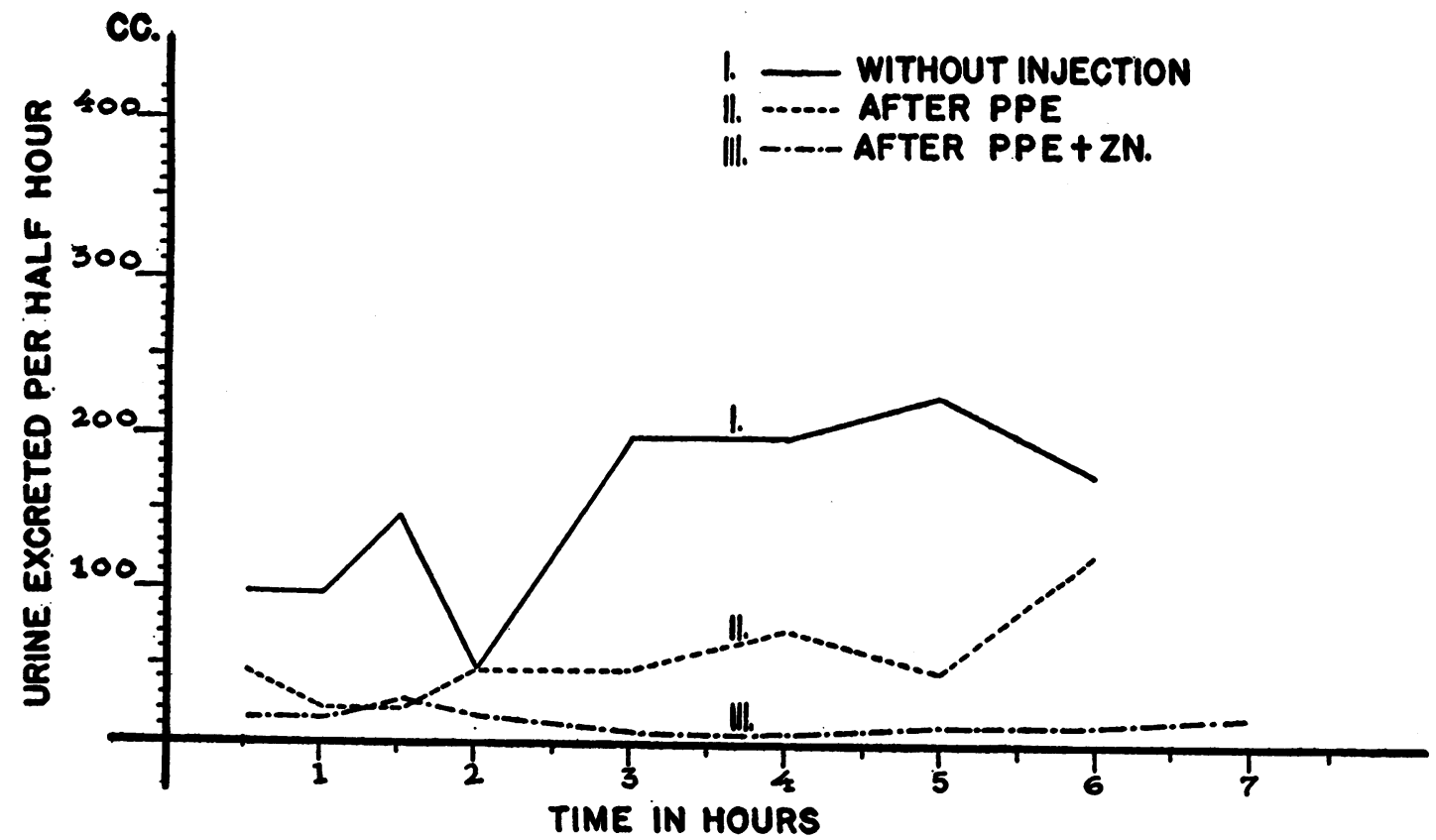

Fig. 2.c

Figs. 2.a, 2.b, and 2.c. The Urine Excretion Curves of Diabetes Insipidus Patients A. F., M. N., and H. F., Following the Intake of 1000 cc. of Tap Water

I. Without medication; II. after the subcutaneous injection of $10 \mathrm{I}$ I.U. of posterior pituitary extract; III. after the subcutaneous injection of $10 \mathrm{I}$.U. of posterior pituitary extract with $1 \mathrm{mgm}$. of zinc. 
seen if the total urine output for corresponding periods is compared (Table I).

Similar experiments were also carried out on 3 male diabetes insipidus patients whose ages ranged from 19 to 43 years. Their first symptoms appeared 3 to 32 years ago, respectively. No medicines were given for 2 days, food was withheld for 12 hours, and fluid intake for 4 hours preceding the experiment. With the administration of $1000 \mathrm{cc}$. of water, a dose of $8 \mathrm{I}$.U. of posterior pituitary extract was injected into the first patient and a dose of 10 I.U. into the second and third patients, in $1 \mathrm{cc}$. lots, with and without the admixture of $1 \mathrm{mgm}$. ( 0.1 per cent) of $\mathrm{Zn}$. The urine output was followed as long as the patients were able to refrain from taking water, but not longer than 8 hours. The results of the experiments are presented in Figures 2.a, 2.b, and 2.c.

Figures 2.a, 2.b, and 2.c show that in every instance there was a great difference in the urine output after drinking $1000 \mathrm{cc}$. of water, depending on whether it was given without posterior pituitary extract, or with the previous injection of posterior pituitary extract alone or posterior pituitary extract plus $\mathrm{Zn}$. Without posterior pituitary extract, the output of a large amount of urine began immediately after the water intake. The administration of posterior pituitary extract prevented the output of a large quantity of urine for 4 hours in the case of A. F., and for 2 hours in the cases of M. N. and H. F. The pronounced effect of posterior pituitary extract with $\mathrm{Zn}$, however, lasted from 6 to 8 hours. It can also be seen from Figures 2.a, 2.b, and 2.c that the rate of excretion was more uniform with posterior pituitary extract and $\mathrm{Zn}$ than with posterior pituitary extract alone.

The effect of the admixture of $\mathrm{Zn}$ is still more striking if the total urine output for corresponding

TABLE II

Total amount of urine collected up to the times indicated

\begin{tabular}{|c|c|c|c|c|c|c|c|c|c|}
\hline \multirow{2}{*}{$\begin{array}{r}\text { Time } \\
\text { from } \\
\text { water } \\
\text { intake }\end{array}$} & \multicolumn{3}{|c|}{ A. F. } & \multicolumn{3}{|c|}{ M. N. } & \multicolumn{3}{|c|}{ H. F. } \\
\hline & $\begin{array}{l}\text { With- } \\
\text { out } \\
\text { injeo- } \\
\text { tion }\end{array}$ & $\begin{array}{l}\text { After } \\
\text { PPE }\end{array}$ & $\begin{array}{l}\text { After } \\
\text { PPE } \\
+Z n\end{array}$ & $\begin{array}{l}\text { With- } \\
\text { out } \\
\text { injec- } \\
\text { tion }\end{array}$ & $\begin{array}{l}\text { After } \\
\text { PPE }\end{array}$ & $\begin{array}{l}\text { After } \\
\text { PPE } \\
+Z \mathbf{Z n}\end{array}$ & $\begin{array}{l}\text { With- } \\
\text { out } \\
\text { injec- } \\
\text { tion }\end{array}$ & $\begin{array}{l}\text { After } \\
\text { PPE }\end{array}$ & $\begin{array}{l}\text { After } \\
\text { PPE } \\
+\mathrm{Zn}\end{array}$ \\
\hline $\begin{array}{c}\text { hours } \\
1 \\
3 \\
6\end{array}$ & $\begin{array}{c}c c . \\
400 \\
1400 \\
1800\end{array}$ & $\begin{array}{c}c c . \\
115 \\
230 \\
675\end{array}$ & $\begin{array}{l}c c . \\
125 \\
215 \\
320\end{array}$ & $\begin{array}{r}c c . \\
950 \\
2275 \\
3185\end{array}$ & $\begin{array}{c}c c . \\
250 \\
900 \\
2025\end{array}$ & $\begin{array}{c}c c . \\
275 \\
425 \\
700\end{array}$ & $\begin{array}{c}c c . \\
200 \\
800 \\
2000\end{array}$ & $\begin{array}{r}c c . \\
75 \\
250 \\
750\end{array}$ & $\begin{array}{r}c c . \\
50 \\
110 \\
190\end{array}$ \\
\hline
\end{tabular}

periods is compared (Table II). It can be seen in Table II that while after the administration of posterior pituitary extract the urine output in 6 hours was 30 to 60 per cent of the quantity passed without medication, the amount of urine passed after posterior pituitary extract with $\mathrm{Zn}$ was only 10 to 20 per cent.

We had the opportunity to observe the water metabolism of these diabetes insipidus patients for a period of 3 to 8 months (Table III). The

TABLE III

Comparison of the action of posterior pituitary extract and posterior pituitary extract with zinc

\begin{tabular}{|c|c|c|c|c|c|c|c|c|c|}
\hline \multirow{2}{*}{$\underset{\text { tient }}{\mathrm{Pa}^{-}}$} & \multirow{2}{*}{$\begin{array}{l}\text { Period } \\
\text { under } \\
\text { obser- } \\
\text { vation }\end{array}$} & \multicolumn{3}{|c|}{$\begin{array}{l}\text { Average urine } \\
\text { excretion in } \\
24 \text { hours }\end{array}$} & \multicolumn{3}{|c|}{ Specific gravity } & \multicolumn{2}{|c|}{$\begin{array}{l}\text { Duration of } \\
\text { pronounced } \\
\text { effect }\end{array}$} \\
\hline & & $\begin{array}{l}\text { With- } \\
\text { out } \\
\text { injec- } \\
\text { tion }\end{array}$ & $\begin{array}{l}\text { After } \\
\text { PPE }\end{array}$ & $\begin{array}{l}\text { After } \\
\text { PPE } \\
+Z n\end{array}$ & $\begin{array}{l}\text { With- } \\
\text { out } \\
\text { injec- } \\
\text { tion }\end{array}$ & $\begin{array}{l}\text { After } \\
\text { PPE }\end{array}$ & $\begin{array}{l}\text { After } \\
\text { PPE } \\
+\mathbf{Z n}\end{array}$ & $\begin{array}{l}\text { After } \\
\text { PPE }\end{array}$ & $\begin{array}{l}\text { After } \\
\text { PPE } \\
+Z \mathbf{n}\end{array}$ \\
\hline & months & \multicolumn{3}{|c|}{ liters } & \multirow[b]{2}{*}{$\begin{array}{l}1.001 \\
1.001 \\
1.001\end{array}$} & \multirow[b]{2}{*}{$\begin{array}{l}1.003 \\
1.002 \\
1.001\end{array}$} & \multirow[b]{2}{*}{$\begin{array}{l}1.007 \\
1.005 \\
1.004\end{array}$} & \multicolumn{2}{|c|}{ hours } \\
\hline $\begin{array}{l}\text { A. F. } \\
\text { M. N. } \\
\text { H. F. }\end{array}$ & $\begin{array}{l}8 \\
6 \\
3\end{array}$ & $\begin{array}{r}9.2 \\
12.5 \\
9.5\end{array}$ & $\begin{array}{l}4.8 \\
8.2 \\
9.0\end{array}$ & $\begin{array}{l}2.4 \\
4.2 \\
5.0\end{array}$ & & & & $\begin{array}{l}3 \text { to } 4 \\
4 \text { to } 5 \\
4 \text { to } 5\end{array}$ & $\begin{array}{l}8 \text { to } 9 \\
9 \text { to } 12 \\
9 \text { to } 15\end{array}$ \\
\hline
\end{tabular}

single daily injection of 10 I.U. of posterior pituitary extract with $\mathrm{Zn}$ has proved to be sufficient to reduce the water intake and urine output to from 50 to 30 per cent, and increase the specific gravity of the urine considerably. In the case of A. F., a single injection every second day was sufficient to obtain this result. The single daily injection of posterior pituitary extract without $\mathrm{Zn}$ had no significant result, either on the water intake or on the urine output of the patients. An average of 2 to 3 daily injections of posterior pituitary extract was necessary to obtain results similar to those observed after single injections of posterior pituitary extract with $\mathrm{Zn}$. While an antidiuretic effect could be demonstrated for 16 to 36 hours after the injection of posterior pituitary extract with $\mathrm{Zn}$, the effect of the same amount of posterior pituitary extract alone lasted only 4 to 8 hours. After the administration of posterior pituitary extract, unwanted side effects (bowel movement, abdominal cramps, pallor, vertigo, etc.) were quite frequent. No such untoward effects were observed after the injection of posterior pituitary extract with $\mathrm{Zn}$. The only difficulty we encountered in the administration of posterior pituitary extract and $\mathrm{Zn}$ was in the case of H. F., in whom some of the injections were 
followed by local pain. Since he usually got on quite well by using hypophysis powder intranasally, we decided to reserve the use of the posterior pituitary extract- $\mathrm{Zn}$ injections for the occasions when, for some reason (sinusitis, coryza), hypophysis powder could not be administered. By changing regularly the site of the injection, no such difficulty was encountered in the other 2 patients.

Considering the above observations, it might be stated that posterior pituitary extract with $\mathrm{Zn}$, when compared with posterior pituitary extract alone, possesses distinct advantages in the treatment of diabetes insipidus patients. Furthermore, it seems possible that $\mathrm{Zn}$ in combination with posterior pituitary extract will prove to be of increasing value in the treatment of certain gynecological, obstetrical, and other conditions where the use of posterior pituitary extract is indicated.

\section{The influence of zinc on the activity of epinephrine ${ }^{8}$}

In preliminary experiments, we found that in man, the optimal $\mathrm{Zn}$ concentration of an epinephrine- $\mathrm{Zn}$ solution is between 0.06 and 0.08 per cent. A 0.2 per cent epinephrine hydrochloride solution (prepared for us by the pharmaceutical firm G. Richter of Budapest) was used throughout the experiments. The observations were made on 4 hospitalized patients, 2 males and 2 females. The age of the patients ranged between 18 and 40 . After 12 hours of bed rest and fasting, the patients received on alternate days $1.6 \mathrm{mgm}$. of epinephrine, and the same amount of epinephrine with $\mathrm{Zn}$, respectively. The volume of the injection was made up to $1 \mathrm{cc}$. in all cases and was injected subcutaneously in the gluteal region. $\mathrm{Zn}$ was added to the epinephrine solution directly before the administration of the injection. Pulse rate, blood pressure, and blood sugar were determined before, and also $1 / 2,1,2,3$, and 4 hours after the injection. The presence and intensity of subjective symptoms (tremor, palpitation, weakness, etc.) were also recorded. The results are tabulated in Table IV and the combined blood sugar curves are given in Figure 3.

It can be seen from Table IV that the admix-

\footnotetext{
6 Dr. L. Kadar (Budapest) cooperated in the experiments with epinephrine.
}

TABLE IV

Comparison of the effect of epinephrine and epinephrine with zinc

\begin{tabular}{|c|c|c|c|c|c|c|c|c|c|}
\hline \multirow[b]{2}{*}{$\underset{\text { tient }}{\mathrm{Pa}-}$} & \multirow{2}{*}{$\begin{array}{l}\text { Time } \\
\text { reck- } \\
\text { oned } \\
\text { from } \\
\text { injec- } \\
\text { tion }\end{array}$} & \multicolumn{4}{|c|}{ After the injection of Adr. } & \multicolumn{4}{|c|}{ After the injection of Adr. $+\mathbf{Z n}$} \\
\hline & & $\begin{array}{l}\text { Pulse } \\
\text { rate }\end{array}$ & $\begin{array}{c}\text { Blood } \\
\text { pressure }\end{array}$ & $\begin{array}{l}\text { Blood } \\
\text { sugar }\end{array}$ & $\begin{array}{l}\text { Sub- } \\
\text { jec- } \\
\text { tive } \\
\text { symp- } \\
\text { toms }\end{array}$ & $\begin{array}{l}\text { Pulse } \\
\text { rate }\end{array}$ & $\begin{array}{c}\text { Blood } \\
\text { pressure }\end{array}$ & $\begin{array}{l}\text { Blood } \\
\text { suzar }\end{array}$ & $\begin{array}{l}\text { Sub- } \\
\text { jec- } \\
\text { tive } \\
\text { symp- } \\
\text { toms }\end{array}$ \\
\hline & hours & & & $\begin{array}{l}\text { mom. } \\
\text { per cent }\end{array}$ & & & & $\begin{array}{c}\text { mom. } \\
\text { per cent }\end{array}$ & \\
\hline A. A. & $\begin{array}{l}0 \\
1 \\
2 \\
1 \\
2 \\
3 \\
4\end{array}$ & $\begin{array}{l}72 \\
78 \\
72 \\
60 \\
66 \\
66\end{array}$ & $\begin{array}{r}100 / 60 \\
120 / 60 \\
120 / 60 \\
100 / 60 \\
90 / 60 \\
90 / 60\end{array}$ & $\begin{array}{r}81 \\
139 \\
163 \\
154 \\
95 \\
65\end{array}$ & \pm & $\begin{array}{l}72 \\
72 \\
72 \\
66 \\
66 \\
66\end{array}$ & $\begin{array}{r}105 / 70 \\
110 / 70 \\
120 / 80 \\
100 / 80 \\
100 / 80 \\
90 / 70\end{array}$ & $\begin{array}{r}83 \\
97 \\
123 \\
154 \\
132 \\
90\end{array}$ & $\begin{array}{l}\bar{z} \\
\bar{t} \\
\overline{-}\end{array}$ \\
\hline E. E. & $\begin{array}{l}0 \\
3 \\
1 \\
1 \\
2 \\
3 \\
4\end{array}$ & $\begin{array}{l}66 \\
78 \\
78 \\
66 \\
66 \\
66\end{array}$ & $\begin{array}{l}120 / 60 \\
130 / 80 \\
120 / 60 \\
105 / 60 \\
105 / 70 \\
100 / 60\end{array}$ & $\begin{array}{r}90 \\
168 \\
175 \\
139 \\
77 \\
70\end{array}$ & $\begin{array}{c}+\overline{+}+ \\
++ \\
= \\
=\end{array}$ & $\begin{array}{l}66 \\
60 \\
66 \\
72 \\
66 \\
66\end{array}$ & $\begin{array}{l}115 / 60 \\
130 / 70 \\
140 / 70 \\
120 / 70 \\
120 / 70 \\
110 / 70\end{array}$ & $\begin{array}{r}83 \\
100 \\
134 \\
161 \\
118 \\
74\end{array}$ & $\begin{array}{l}\bar{z} \\
\bar{z} \\
\overline{-}\end{array}$ \\
\hline E. W. & $\begin{array}{l}0 \\
3 \\
1 \\
1 \\
2 \\
3 \\
4\end{array}$ & $\begin{array}{l}72 \\
84 \\
96 \\
92 \\
80 \\
90\end{array}$ & $\begin{array}{l}110 / 70 \\
130 / 60 \\
126 / 60 \\
115 / 60 \\
105 / 60 \\
105 / 60\end{array}$ & $\begin{array}{r}83 \\
161 \\
188 \\
156 \\
85 \\
65\end{array}$ & $\begin{array}{c}\overline{+}+ \\
+++ \\
++ \\
-\end{array}$ & $\begin{array}{l}78 \\
84 \\
84 \\
84 \\
84 \\
84\end{array}$ & $\begin{array}{l}100 / 70 \\
110 / 60 \\
120 / 60 \\
110 / 70 \\
110 / 60 \\
100 / 60\end{array}$ & $\begin{array}{r}85 \\
123 \\
166 \\
211 \\
166 \\
95\end{array}$ & $\begin{array}{l}\bar{z} \\
\bar{t} \\
\overline{-}\end{array}$ \\
\hline E. $\mathbf{P}$. & $\begin{array}{l}0 \\
1 \\
\frac{1}{2} \\
1 \\
2 \\
3 \\
4\end{array}$ & $\begin{array}{r}96 \\
114 \\
120 \\
114 \\
96 \\
90\end{array}$ & $\begin{array}{l}105 / 80 \\
140 / 80 \\
140 / 70 \\
128 / 70 \\
110 / 70 \\
110 / 70\end{array}$ & $\begin{array}{r}74 \\
129 \\
143 \\
123 \\
85 \\
65\end{array}$ & $\begin{array}{c}- \\
++ \\
++ \\
+ \\
\pm\end{array}$ & $\begin{array}{l}90 \\
96 \\
96 \\
96 \\
96 \\
90\end{array}$ & $\begin{array}{l}120 / 80 \\
115 / 80 \\
125 / 70 \\
120 / 70 \\
120 / 70 \\
110 / 65\end{array}$ & $\begin{array}{r}72 \\
97 \\
111 \\
150 \\
116 \\
76\end{array}$ & $\begin{array}{l}\bar{z} \\
\bar{z}\end{array}$ \\
\hline
\end{tabular}

ture of $\mathrm{Zn}$ decreased and postponed the elevation of pulse rate and postponed the blood pressure response caused by the administration of epinephrine. Moreover, there was a significant decrease both in the intensity and duration of the unwanted side effects (tremor, palpitation, etc.).

The behavior of the blood sugar curve (Figure 3) has been particularly interesting. Following the injection of epinephrine plus $\mathrm{Zn}$, the initial rise of the curve was moderate, the maximum was reached later and the elevation lasted longer than after the injection of epinephrine alone. The hyperglycemic effects of epinephrine alone, and of epinephrine with $\mathrm{Zn}$, respectively, can be measured by the surface area bounded by the blood sugar curves and lines parallel with the $\mathrm{X}$ axis drawn through the starting point of the curves. The area representing the effect of epinephrine alone was found to be 54.0 units, that of epinephrine with $\mathrm{Zn} 76.8$ units, so that there is a difference of 42 per cent between the two values to the advantage of the latter.

Case A. A. has been a chronic asthmatic patient hospitalized for the frequency of his seizures. He regularly had an attack just after awakening in 


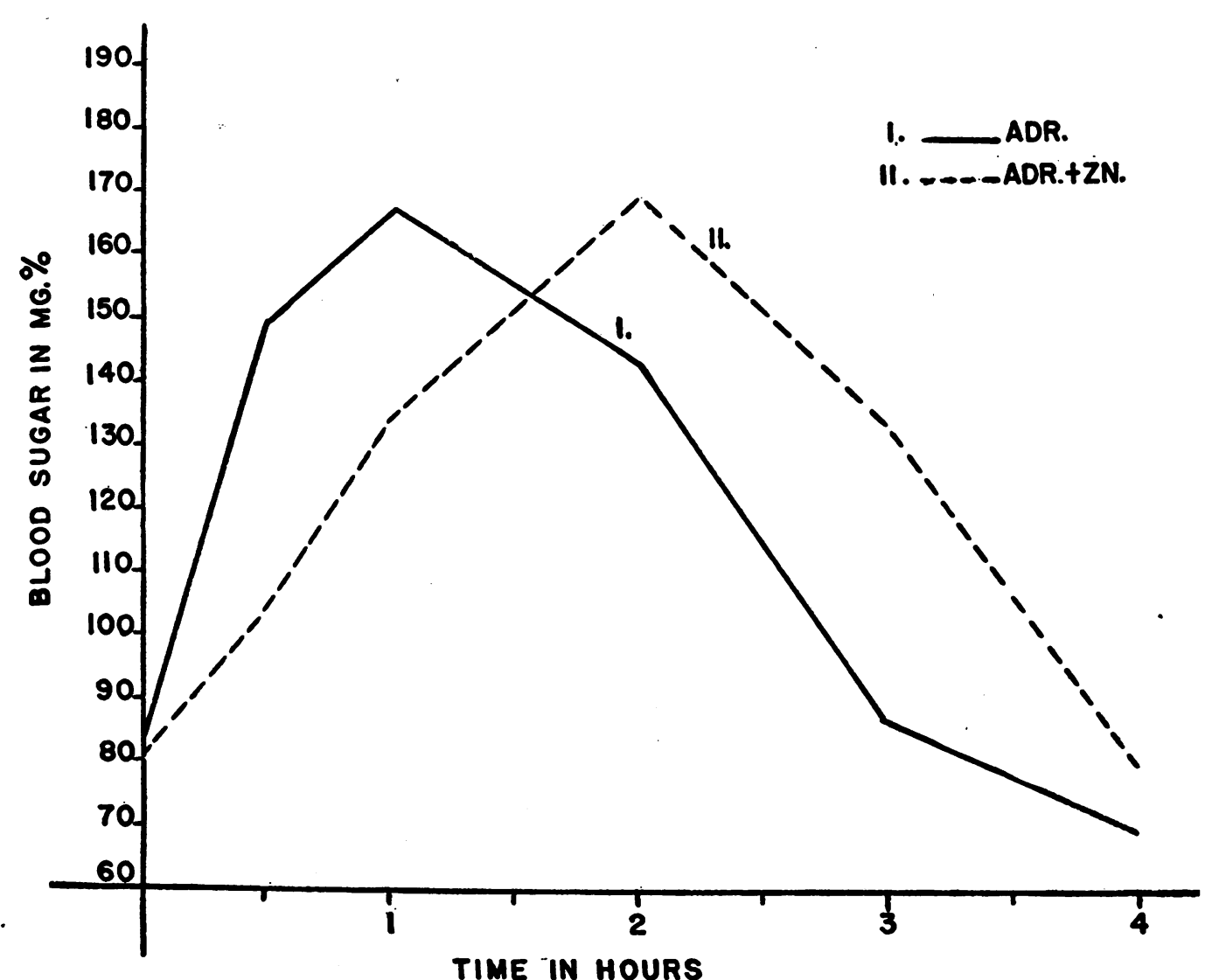

Fig. 3. The Combined Blood Sugar Curves of 4 Patients, Following the Subcutaneous Administration of 1.6 MgM. OF EpINEPHRINe, AND 1.6 MgM. OF EPINEPHRINe With 0.8 MgM. OF ZiNC

the morning. The experiments were timed to begin shortly after the attack had developed fully. To our surprise, there was no delay in the onset of the antiasthmatic effect of epinephrine when injected together with $\mathrm{Zn}$. On the other hand, while the effect of epinephrine alone lasted only 3 to 4 hours, epinephrine with $\mathrm{Zn}$ was still effective after 6 to 8 hours. On other asthmatic patients, a mixture containing $1.2 \mathrm{mgm}$. of epinephrine, 5 I.U. of posterior pituitary extract, and 0.08 per cent of $\mathrm{Zn}$ proved to have an antiasthmatic effect for 16 to 24 hours.

Another field where epinephrine with $\mathrm{Zn}$ has been used effectively is dentistry. The unwanted side effects (pallor, tremor, weakness of the extremities, elevation of blood pressure, etc.) after dental analgesic injections containing epinephrine, are well known. All these symptoms are caused by the general action of epinephrine which is, in these cases, unnecessary, since only the local vaso- constrictor effect is wanted. By the addition of 0.08 to 0.1 per cent of $\mathrm{Zn}$ to the analgesic epinephrine mixture, the unwanted side effects were ruled out completely. A limited number of trials were carried out which not only proved the absence of the unwanted side effects, but also seemed to show a more prolonged local anesthesia.

As already mentioned, there is a distinct discrepancy between the results of Kohn and Bulger (10) and our own experiments. It seems possible that the explanation of this difference might be in the dosage employed. Taking it for granted that the epinephrine preparations used were of equal strength, our dose (1.6 mgm.) was more than three times larger than theirs $(0.5 \mathrm{mgm}$.). A dose of $0.5 \mathrm{mgm}$. of epinephrine if absorbed rapidly is able to produce a marked hyperglycemia. If, however, its absorption is delayed, or distributed over a longer period of time, the threshold necessary for the production of hyperglycemia will 
not be reached, due to the rapid destruction of epinephrine. Since epinephrine is a vasoconstrictor drug which slows up its own resorption to a certain extent, even small quantities of $\mathrm{Zn}$ suffice to impede the absorption of a borderline dose of 0.5 mgm., and to prevent a pronounced hyperglycemic effect. On the other hand, if larger doses are applied, the necessary concentration for the production of hyperglycemia will be reached. This coincides with the ultimate objective of the prolongation of the action of medicines, namely: the attainment of a prolonged effect by means of the gradual and evenly distributed resorption of a single large dose.

These preliminary observations on the application of epinephrine with $\mathrm{Zn}$ indicate that the admixture of 0.06 to 0.08 per cent of $\mathrm{Zn}$ to a subcutaneously injected epinephrine solution diminishes the unwanted side effects and prolongs its period of activity, as measured by the hyperglycemic action.

\section{The effect of zinc on the urinary excretion of thiamine hydrochloride after subcutaneous injection?}

It is well known that after the parenteral administration of thiamine, a varying amount of the vitamin injected will be excreted in the urine. The amount excreted depends upon the degree to which the injected person is saturated with thiamine. According to Magyar (11) and Hills (12), less than 18 per cent of the amount injected will be excreted if the patients have latent or manifest thiamine deficiency. It is very interesting that the percentage proportion of the excreted thiamine is fairly independent of the absolute amount injected, and that approximately the same percentage of the quantity injected can be recovered from the urine whether 10 or $50 \mathrm{mgm}$. were administered parenterally. Magyar (11), Hills (12), and Goth (13) report that the majority of the excreted thiamine can be found in the urine passed within one hour after the administration of the vitamin. We presumed that this rapid excretion was due to the high blood levels which follow parenteral administration, and that by slowing down the rate of absorption by

7 Dr. E. Goth (Budapest) cooperated in the experiments with thiamine. the admixture of 0.1 per cent of $\mathrm{Zn}$, the amount of thiamine to be excreted might be reduced.

The experiments were carried out on 5 hospitalized patients and 2 healthy persons. The thiamine excretion was tested on 4 of these after the repeated administration of $10 \mathrm{mgm}$. doses, on 3 after the administration of $50 \mathrm{mgm}$. doses, and on 1 after the administration of both 10 and $50 \mathrm{mgm}$. doses. Urine was collected from the experimental persons $1 / 2,1,2,3,5,8$, and 24 hours after the injection of thiamine alone or thiamine with $\mathrm{Zn}$. The site of the injection was the gluteal region. The amount of thiamine excreted in the urine was determined by the thiochrome method as modified by Ritsert (14).

The results following the administration of the $10 \mathrm{mgm}$. dose, with and without $\mathrm{Zn}$, are presented in Table V. It can be seen from Table $V$ that

TABLE $V$

Incremental $B_{1}$ excretion at the times indicated, following the s.c. injection of $10 \mathrm{mgm}$. $B_{1}$

\begin{tabular}{|c|c|c|c|c|c|c|c|c|}
\hline Patient & Injection & hour & $\stackrel{1}{1}$ & $\underset{\text { hours }}{2}$ & $\begin{array}{c}3 \\
\text { hours }\end{array}$ & $\begin{array}{c}5 \\
\text { hours }\end{array}$ & $\begin{array}{c}8 \\
\text { hours }\end{array}$ & $\underset{\text { hours }}{24}$ \\
\hline \multirow{3}{*}{ F. F. } & & \multicolumn{7}{|c|}{ micrograms } \\
\hline & $\mathbf{B}_{\mathbf{1}}$ & 362 & 744 & 465 & 208 & 178 & 124 & 400 \\
\hline & $B_{1}+Z_{n}$ & 38 & 96 & 112 & 651 & 192 & 884 & 224 \\
\hline \multirow{2}{*}{ E. G. } & $\mathrm{B}_{1}$ & 588 & 1066 & 777 & 416 & 180 & 86 & 372 \\
\hline & $B_{1}+Z n$ & 90 & 450 & 66 & 180 & 260 & 57 & 221 \\
\hline \multirow{2}{*}{ M. B. } & $\mathbf{B}_{\mathbf{1}}$ & 660 & 460 & 256 & 52 & 61 & 44 & 210 \\
\hline & $B_{1}+Z_{n}$ & 192 & 205 & 512 & 201 & 88 & 57 & 280 \\
\hline \multirow{2}{*}{ N. L. } & $\mathbf{B}_{\mathbf{1}}$ & 400 & 148 & 180 & 80 & 59 & 61 & 256 \\
\hline & $B_{1}+Z n$ & 56 & 60 & 166 & 43 & 80 & 25 & 153 \\
\hline \multirow{2}{*}{ T. M. } & $\mathbf{B}_{\mathbf{1}}$ & 902 & 396 & 480 & 228 & 326 & 140 & 540 \\
\hline & $B_{1}+Z n$ & 300 & 280 & 720 & 202 & 36 & 138 & 528 \\
\hline
\end{tabular}

after the administration of $10 \mathrm{mgm}$. of thiamine alone, the intensity of excretion reached its maximum in $1 / 2$ hour in 3 cases and in 1 hour in the other 2 cases. If the same amount of thiamine was injected with $\mathrm{Zn}$, the maximal excretion occurred 3 hours after the injection in 1 case, 2 hours after the injection in 3 cases, and 1 hour after the injection in 1 case. The difference between the utilization of thiamine alone and thiamine with $\mathrm{Zn}$ can be clearly seen from Table VI in which the total amounts of thiamine excreted during corresponding periods are compared. According to the figures of this table, the quantity of thiamine excreted in a 24-hour period, after 


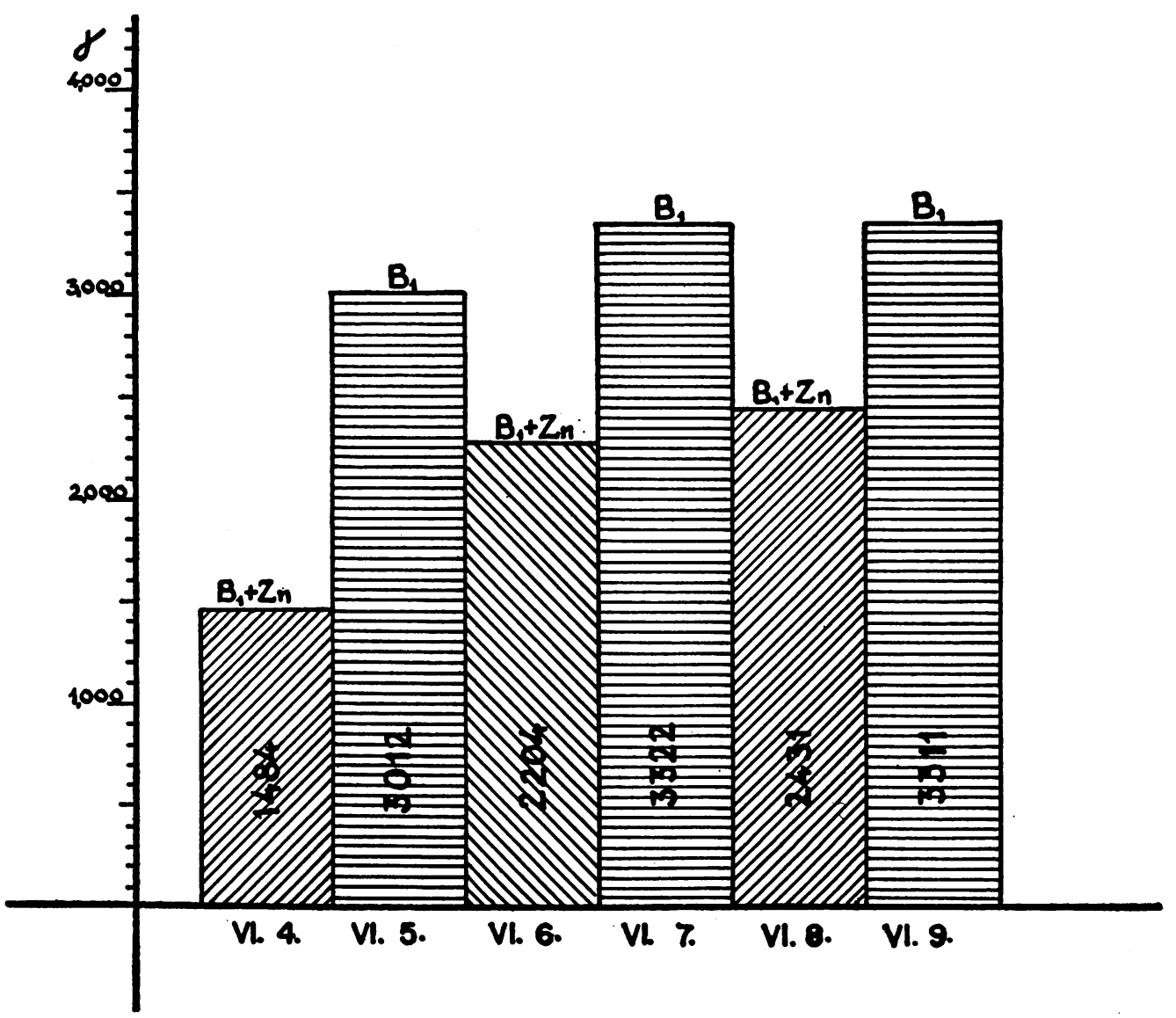

Fig. 4. The Amount of Thiamine Excreted in 24-hour Periods After the Alternating Daily Injections of 10 mgm. of Thiamine Hydrochloride, With and Without the Addition OF 1 MGM. OF ZiNC

TABLE VI

Total amount of $B_{1}$ excreted up to the times indicated, following the s.c. injection of $10 \mathrm{mgm} . B_{1}$

\begin{tabular}{c|c|r|r|r|r}
\hline \hline Patient & Injection & 1 hour & 2 hours & 3 hours & 24 hours \\
\cline { 3 - 6 } F. F. & $\mathrm{B}_{1}$ & 1106 & 1571 & 1779 & 2481 \\
& $\mathrm{~B}_{1}+\mathrm{Zn}$ & 134 & 246 & 797 & 1400 \\
E. G. & $\mathrm{B}_{1}$ & 1654 & 2431 & 2847 & 3485 \\
& $\mathrm{~B}_{1}+\mathrm{Zn}$ & 540 & 606 & 786 & 1324 \\
M. B. & $\mathrm{B}_{1}$ & 1120 & 1376 & 1428 & 1743 \\
& $\mathrm{~B}_{1}+\mathrm{Zn}$ & 397 & 909 & 1110 & 1535 \\
N. L. & $\mathrm{B}_{1}$ & 548 & 728 & 808 & 1184 \\
& $\mathrm{~B}_{1}+\mathrm{Zn}$ & 116 & 282 & 325 & 583 \\
T. M. & $\mathrm{B}_{1}$ & 1298 & 1778 & 2006 & 3012 \\
& $\mathrm{~B}_{1}+\mathrm{Zn}$ & 580 & 1300 & 1500 & 2200 \\
\hline
\end{tabular}

the injection of $10 \mathrm{mgm}$. of thiamine with $\mathrm{Zn}$, is considerably ( 12 to 63 per cent) less than if thiamine alone had been injected. Furthermore, Table VI also shows that a much larger proportion of the total was excreted in the first 3 hours after the injection of thiamine alone, than after the administration of thiamine with $\mathrm{Zn}$. In the case of M. B., we followed up the thiamine excretion after the alternating daily injection of 10 mgm. of thiamine and thiamine with $\mathrm{Zn}$. On every occasion, less thiamine was excreted in the urine after the injection of thiamine and $\mathrm{Zn}$, than after the injection of thiamine alone (Figure 4).

Similar results were obtained if the dose of the administered vitamin was increased to $50 \mathrm{mgm}$. (Tables VII and VIII).

These results (even if the limitations of the thiochrome method are considered) indicate that the addition of 0.1 per cent of $\mathrm{Zn}$ to thiamine in- 
TABLE VII

Incremental $B_{1}$ excretion at the times indicated, following the s.c. injection of $50 \mathrm{mgm}$. $B_{1}$

\begin{tabular}{l|c|r|r|r|r|r|r|r}
\hline \hline Patient & Injection & hour & $\begin{array}{c}1 \\
\text { hour }\end{array}$ & $\begin{array}{c}2 \\
\text { hours }\end{array}$ & $\begin{array}{c}3 \\
\text { hours }\end{array}$ & $\begin{array}{c}5 \\
\text { hours }\end{array}$ & $\begin{array}{c}8 \\
\text { hours }\end{array}$ & $\begin{array}{c}24 \\
\text { hours }\end{array}$ \\
\hline & & \multicolumn{6}{|c}{ micrograms } \\
P.P. & $B_{1}$ & 10296 & 3848 & 1536 & 4200 & 648 & 350 & 750 \\
& $B_{1}+Z n$ & 1332 & 3400 & 4737 & 1250 & 960 & 820 & 1400 \\
M. T. & $B_{1}$ & 4080 & 1848 & 1932 & 620 & 284 & 136 & 450 \\
& $B_{1}+Z n$ & 1420 & 1668 & 1340 & 853 & 640 & 1044 & 800 \\
K. I. & $B_{1}$ & 6120 & 2112 & 898 & 317 & 368 & 407 & 1610 \\
& $B_{1}+Z n$ & 2928 & 3420 & 7008 & 1480 & 270 & 840 & 800 \\
\hline
\end{tabular}

TABLE VIII

Total amount of $B_{1}$ excreted up to the times indicated, following the s.c. infection of $50 \mathrm{mgm} . B_{1}$

\begin{tabular}{l|c|r|r|r|r}
\hline \hline Patient & \multirow{2}{*}{ Injection } & 1 hour & 2 hours & 3 hours & 24 hours \\
\cline { 3 - 6 } P.P. & $B_{1}$ & 14144 & 15680 & 19880 & 21928 \\
& $B_{1}+Z n$ & 4732 & 9469 & 10719 & 13899 \\
M. T. & $B_{1}$ & 5928 & 7860 & 8480 & 9350 \\
& $B_{1}+Z n$ & 3088 & 4428 & 5281 & 7785 \\
K. I. & $B_{1}$ & 8232 & 9130 & 9447 & 11832 \\
& $B_{1}+Z n$ & 6348 & 14056 & 15546 & 16856 \\
\hline
\end{tabular}

jected subcutaneously not only delays its excretion but also diminishes the total amount of thiamine to be excreted in a 24-hour period.

\section{COMMENT}

Since this work has been an attempt to employ $\mathrm{Zn}$ for the prolongation of the action of subcutaneously injected medicines, perhaps it is not superfluous to see how this effect of $\mathrm{Zn}$, and other metal salts, is brought about. $\mathrm{ZnCl}_{2}$ is readily dissolved in an aqueous medium of acid reaction. If however the $\mathrm{pH}$ of such a $\mathrm{ZnCl}_{2}$ solution is shifted towards the alkaline, then above $\mathrm{pH} \mathrm{5.5,} \mathrm{a}$ fine precipitate forms which consists of $\mathrm{Zn}(\mathrm{OCl})_{2}$ and $\mathrm{Zn}(\mathrm{OH})_{2}$. Furthermore, if an acid solution containing $\mathrm{ZnCl}_{2}$ is injected into subcutaneous tissue of about $7.4 \mathrm{pH}$, not only $\mathrm{Zn}(\mathrm{OCl})_{2}$ and $\mathrm{Zn}(\mathrm{OH})_{2}$ are formed, but also some of the proteins of the tissue fluids are precipitated by the $\mathrm{Zn}$ ions. The precipitate thus formed encloses the therapeutic agent injected, together with the $\mathrm{ZnCl}_{2}$ solution. According to the principles of physical chemistry, strong diffusion should start in the direction of the relatively insoluble precipitate. Consequently, the rapid absorption of the injected therapeutic agent will be hindered. Its absorption can only occur gradually, partly by osmosis, and partly by the breaking down of the precipitate. That this is the sequence of events was ingeniously demonstrated by Sahyun (3.d) in experiments made on the ear of the rabbit.

In animal experiments, it was possible to show (9) that the prolonging effect of $\mathrm{ZnCl}_{2}$ depends not only on the $\mathrm{Zn}$ concentration of the injected material, but also on the site of the injection. Provided that the $\mathrm{Zn}$ concentration of the injected substance is kept constant, the prolonging effect is the more pronounced, the more dense the subcutaneous tissue where it is injected. The probable explanation of this observation is that in densely woven tissues, the reaction between the injected material and the tissue proteins is more complete and the absorptive surface is also smaller.

The subcutis of man, especially that of the thigh and the gluteal region, is much more suitable for the development of the above reaction than the subcutis of any laboratory animal. Consequently, the amount of $\mathrm{Zn}$ necessary to produce maximal prolongation of the effect of posterior pituitary extract and epinephrine is much less ( 0.1 per cent and 0.06 per cent) in man than in rats ( 0.5 per cent to 1.0 per cent, Dodds (4.a)) or rabbits (1.2 per cent (Foldes (9)). This is of practical importance because solutions containing less than 0.12 per cent $\mathrm{Zn}$ can be injected subcutaneously without any gross local reaction or major discomfort. No general ill effects were observed after the daily administration over a period of more than 6 months. That such small $\mathrm{Zn}$ doses should produce any toxic symptoms, even after prolonged administration, seems improbable if we consider that there are 5 to $10 \mathrm{mgm}$. of $\mathrm{Zn}$ present in the average daily diet, and that $\mathrm{Zn}$ has been shown to be indispensable in the normal development of certain animals (15).

The fact that on one hand it has been possible to prolong the activity of such widely differing substances as posterior pituitary extract, epinephrine, and thiamine, and on the other hand, that 
more than one agent has been found suitable for prolonging the effect of the same substance (e.g. tartrate and $\mathrm{Zn}$ in the case of posterior pituitary extract) seems to be encouraging as to the future possibilities of this kind of therapy.

\section{SUMMARY}

1. Zinc, in a concentration of 0.06 to 0.1 per cent, has been found to be effective in prolonging the antidiuretic effect of posterior pituitary extract and the hyperglycemic effect of epinephrine.

2. The admixture of zinc also diminished the development of unwanted side effects of both posterior pituitary extract and epinephrine.

3. Posterior pituitary extract with zinc has been successfully employed in the treatment of 3 diabetes insipidus patients.

4. The same zinc concentration delayed and diminished the urinary excretion of thiamine after subcutaneous administration.

5. The prolonging effect of zinc depends not only on its concentration, but also on the site of the injection.

6. The desirability of a systematic study of the prolongation of the effect of other subcutaneously injected medicines is indicated.

\section{BIBLIOGRAPHY}

1. Bertrand, G., and Mâcheboeuf, M., Influence du nickel et du cobalt sur l'action exercée par l'insuline, chez le lapin. Compt. rend. Acad. d. sc., 1926, 182, 1504.

2.a. Maxwell, L. C., The quantitative and qualitative ovarian response to distributed dosage with gonadotropic extracts. Am. J. Physiol., 1934, 110, 458.

b. Bischoff, F., The influence of divided dosage of gonadotropic extracts in the immature male rat. Am. J. Physiol., 1936, 114, 483.

c. Fevold, H. L., Hisaw, F. L., and Greep, R. O., Augmentation of the gonad stimulating action of pituitary extracts by inorganic substances, particularly copper salts. Am. J. Physiol., 1936, 117, 68.

d. Saunders, F. J., and Cole, H. H., Means of augmenting the ovarian response to gonadotropic substances. Proc. Soc. Exper. Biol. and Med., 1936, 33, 505 .

e. Bischoff, F., Factors influencing the augmentation effects produced by zinc or copper when mixed with gonadotropic extracts. Am. J. Physiol., 1938, 121, 765.

3.a. Scott, D. A., and Fisher, A. M., The effect of zinc salts on the action of insulin. J. Pharmacol. and Exper. Therap., 1935, 55, 206. b. Fazekas, J. F., and Himwich, H. E., The effect of zinc and aluminum on the hypoglycemic effect of insulin. J. Pharmacol. and Exper. Therap., 1936, $58,260$.

c. Bavin, E. M., and Broom, W. A., Effect of certain substances on absorption of insulin; metals. Quart. J. Pharm. and Pharmacol., 1937, 10, 327.

d. Sahyun, M., Effect of zinc on insulin and its mechanism. Am. J. Physiol., 1939, 125, 24.

4.a. Dodds, E. C., Noble, R. L., Rinderknecht, H., and Williams, P. C., Prolongation of action of the pituitary antidiuretic substance and of histamine by metallic salts. Lancet, 1937, 2, 309.

b. Noble, R. L., Rinderknecht, H., and Williams, P. C., Apparent augmentation of the pituitary antidiuretic action, by various retarding substances. J. Physiol., 1939, 96, 293.

c. Boyd, E. M., and Clark, K. J., The prolongation by zinc salts of a water balance reaction of posterior hypophyseal extract. Am. J. M. Sc., 1939, 198, 171.

d. Stephens, D. J., Zinc salts and oil in prolongation of therapeutic effect of pitressin in experimental diabetes insipidus. Proc. Soc. Exper. Biol. and Med., 1940, 44, 240.

5. Schwab, H., Modifications apportées á l'action hyperglycémiante de l'adrénaline, par addition de sels de zinc. Compt. rend. Acad. d. sc., 1937, 205, 628.

6. Handley, C. A., Emerson, G. A., and Abreu, B. E., Effects of mixtures of morphine and zinc sulfate on blood sugar. Univ. California Publ., Pharmacol., $1940,1,321$.

7. Hagedorn, H. C., Jensen, B. N., Krarup, N. B., and Wodstrup, I., Protamine insulinate. J. A. M. A., 1936, 106, 177.

8.a. Court, D., and Taylor, S. A., Diabetes insipidus treated by slowly acting pituitary emulsion. Proc. Roy. Soc. Med., 1939, 32, 1203.

b. Wankmüller, R., Über die Wirksamkeit eines Tonephindepots beim Diabetes insipidus. Klin. Wchnschr., 1939, 18, 566.

c. Greene, J. A., and January, L. E., Efficacy of pellets of posterior hypophysis and of pitressin in oil in diabetes insipidus. Proc. Soc. Exper. Biol. and Med., 1940, 44, 217.

d. Greene, J. A., and January, L. E., Diabetes insipidus treated by the subcutaneous administration of a suspension of pitressin tannate in oil. J. A. M. A., 1940, 115, 1183.

e. Foldes, F., and Strausz, E., Prolongation of antidiuretic effect of posterior pituitary extract by addition of zinc salts: Preliminary report. Schweiz. Med. Wchnschr., 1942, 72, 314.

9. Foldes, F. F., The effect of zinc on the hyperglycemic action of epinephrine in rabbits. (To be published.)

10. Kohn, E., and Bulger, H. A., Action of zinc on effect of adrenalin given subcutaneously. Proc. Soc. Exper. Biol. and Med., 1937, 37, 421. 
11. Magyar, I., $B_{1}$ Vitamin im Harn nach Belastung mit grossen Dosen. Klin. Wchnschr., 1941, 20, 425.

12. Hills, G. M., The thiochrome test for aneurin (vitamin $B_{1}$ ) in urine as an index of nutritional level. Biochem. J., 1939, 33, 1966.

13. Goth, E., Diagnosis of thiamine hydrochloride deficiency. Orvosi hetil., 1941, 85, 138.

14. Ritsert, $K$., Uber die Ausscheidung von peroral und parenteral zugeführten Aneurin. Klin. Wchnschr., 1938, 17, 1397.

15.a. Scoular, F. I., A quantitative study by means of spectrographic analysis of zinc in nutrition. J. Nutrition, 1939, 17, 103.

b. Hove, E., Elvehjem, C. A., and Hart, E. B., Further studies on zinc deficiency in rats. Am. J. Physiol., 1938, 124, 750. 